\title{
An epidemiologic overview of acute kidney injury in intensive care units
}

\author{
(iD) Reginaldo Passoni dos Santos ${ }^{*}$ \\ (iD) Ariana Rodrigues Silva Carvalho',2 \\ (iD) Luis Alberto Batista Peres ${ }^{1,3}$ \\ Claudio Ronco ${ }^{4}$ \\ Etienne Macedo ${ }^{5}$
}

\begin{abstract}
1. Programa de Pós-Graduação em Biociências e Saúde, Universidade Estadual do Oeste do Paraná - Cascavel, PR, Brasil 2. Departamento de Enfermagem, Universidade Estadual do Oeste do Paraná - Cascavel, PR, Brasil 3. Departamento de Medicina, Divisão de Nefrologia, Universidade Estadual do Oeste do Paraná - Cascavel, PR, Brasil 4. San Bortolo of Vicenza; Department of Nephorology, Dialysis \& Transplantation; International Renal Research Institute - Vicenza, Italy. 5. University of California San Diego, Department of Medicine, Division of Nephrology - California, United States of America
\end{abstract}

http://dx.doi.org/10.1590/1806-9282.65.8.1094

\section{SUMMARY}

INTRODUCTION: Acute kidney injury (AKI) is a frequent event among critically ill patients hospitalized in intensive care units (ICU) and represents a global public health problem, being imperative an interdisciplinary approach.

OBJECTIVE: To investigate, through literature review, the AKI epidemiology in ICUs.

METHODS: Online research in Medline, Scientific Electronic Library Online, and Latin American and Caribbean Literature in Health Sciences databases, with analysis of the most relevant 47 studies published between 2010 and 2017.

RESULTS: Data of the 67,033 patients from more than 300 ICUs from different regions of the world were analyzed. The overall incidence of AKI ranged from $2.5 \%$ to $92.2 \%$, and the mortality from $5 \%$ to $80 \%$. The length of ICU stay ranged from five to twenty-one days, and the need for renal replacement therapy from 0.8\% to 59.2\%. AKI patients had substantially higher mortality rates and longer hospital stays than patients without AKI.

CONCLUSION: AKI incidence presented high variability among the studies. One of the reasons for that were the different criteria used to define the cases. Availability of local resources, renal replacement therapy needs, serum creatinine at ICU admission, volume overload, and sepsis, among others, influence mortality rates in AKI patients.

KEYWORDS: Acute kidney injury. Intensive care units. Epidemiology. Risk factors.

\section{INTRODUCTION}

Acute kidney injury (AKI) occurs most frequently in critically ill patients admitted to an intensive care unit (ICU) and represents a global public health problem. ${ }^{1,2}$ The implications of AKI go beyond the care context and involve considerable expenditure for health care institutions and systems, as well as contributing to a reduction in patients' quality of life. ${ }^{3,4}$ In 2014 , the International Society of Nephrology launched the "Oby25" Project, aiming to reduce avoidable death due to AKI worldwide by promoting universal actions and encouraging scientific dissemination on the subject. ${ }^{5}$ Thus, this study aimed to investigate the AKI epidemiology in ICUs. 


\section{METHODS}

We searched the MEDLINE, Scientific Electronic Library Online, and Latin American and Caribbean Literature in Health Sciences databases for original articles published in English, Portuguese, and Spanish, with information available about the incidence or mortality of critically ill AKI patients admitted to ICUs. The keywords used in the search were: "acute kidney injury”, “intensive care unit”, and, “epidemiology" with the application of the Boolean operator "AND." The search occurred between January to February 2018.

\section{RESULTS}

Forty-seven studies analyzing data from 67,033 patients from more than 300 ICUs located in different regions of the world were included in this review. The overall incidence of AKI ranged from $2.5 \%{ }^{6}$ to $92.2 \%^{7}$ and mortality from $5 \%^{8,9}$ to $80 \%$, reaching $100 \%$ in patients who undergo renal replacement therapy (RRT). ${ }^{10-12}$

Among the papers included in this review, 28 reflect data from developing countries, 17 from developed nations, and 2 are multinational, including countries with different income categories. The mean AKI incidence in developed and developing countries was $33.4 \%$ and $37.7 \%$, while the mean mortality rate was $40.6 \%$ and $43.2 \%$, respectively.

The need for RRT was between $0.8 \%{ }^{13}$ and $59.2 \%{ }^{14}$ and the ICU, and hospital stay length varied from ${ }^{52,15}$ to 21 days $^{16}$ and from 102 to 36 days, ${ }^{17}$ respectively. Overall, AKI patients showed a risk of mortality almost 50\% higher than patients without AKI, and their hospital stay was up to ten days longer (see Table 1).

\section{DISCUSSION}

The use of different diagnostic criteria is one of the factors that contributed to the discrepancies observed in the studies in AKI incidence rate. ${ }^{18,19}$ About the geographical location, we verified that AKI-associated mortality rate was higher in developing countries. As demonstrated by another international multicenter study, ${ }^{2}$ the risk of death in cases of AKI in ICU is four-fold higher in emerging countries, mainly due to the limited resources available for the adequate/early management of the event.

The AKI occurrence in ICU increases length of stay, need for more vasopressors drugs and special- ized human resources, increasing the cost of services and health care systems. The limitation of all these resources and the observed reality in emerging countries contribute to the increase in patients' morbidity and mortality in regions with lower resources.

Furthermore, the population and the total number of participants included in a study should also be considered. A study reported AKI incidence of 2.5\% based on data from approximately 8,000 patients enrolled from the database Multiparameter Intelligent Monitoring in Intensive Care-II. ${ }^{6}$ Whereas, in a study analyzing data from a single-center survey with 51 patients in the postoperative period of cardiac surgery had an incidence higher than $90 \%{ }^{7}$

In two recent multinational, multicenter studies ${ }^{\mathbf{1 , 2}}$ included in this review, the mean incidence of the event was $40.5 \%$, and the mean ICU mortality was $23 \%$, reaching more than $30 \%$ among cases that required RRT. In another multinational study published in 2005, AKI incidence in critically ill patients was close to $6 \%$, the need for RRT was higher than $70 \%$, and the mortality predicted in the ICU was $45.6 \%{ }^{20}$

These data show that the burden of AKI worldwide is alarming and has been increasing over the past ten years, requiring that the biomedical model of care be replaced by an interdisciplinary health care model, in which actions are planned by a multi-professional health team. In addition, physicians of different specialties (intensivists, nephrologists, and others) should work with a specialized nursing team, pharmacists, physiotherapists, and nutritionists, each bringing their specific professional expertise to integrate quality intensive care. ${ }^{1-4}$

The demographic transition that has taken place in developed nations and, more recently in developing countries, has also brought clinical-epidemiological changes in the population profile, expressed by the increase in the life expectancy of individuals. Old age and chronic diseases are among the main AKI risk factors, as they result in systemic and permanent metabolic-physiological alterations that lead to decreased basal organic-functional kidney activity. ${ }^{21}$ However, these changes have also incurred an increase in the burden brought about by chronic-degenerative pathological conditions. ${ }^{22}$

Zhou et al. ${ }^{23}$ reported a significant risk for incidence or death from AKI in ICU among individuals over 50 years of age. However, other studies have shown that morbidity and mortality are especially high among individuals older than 60 , and the risk 
TABLE 1. SUMMARY OF INFORMATION ABOUT THE EPIDEMIOLOGY OF AKI PRESENTED IN THE REVISED ARTICLES*.

\begin{tabular}{|c|c|c|c|c|c|c|c|c|c|c|c|c|}
\hline \multirow{3}{*}{ Ref } & \multicolumn{2}{|c|}{ Patients } & \multirow{3}{*}{$\begin{array}{l}\text { Criteria } \\
\text { for AKI }\end{array}$} & \multicolumn{9}{|c|}{ Epidemiological data of AKI } \\
\hline & \multirow[t]{2}{*}{$n$} & \multirow[t]{2}{*}{ Setting } & & \multirow{2}{*}{$\begin{array}{l}\text { Incidence } \\
(\%)\end{array}$} & \multirow[t]{2}{*}{ RRT (\%) } & \multirow{2}{*}{$\begin{array}{l}\text { Mortality } \\
\text { endpoint }\end{array}$} & \multicolumn{3}{|c|}{ Mortality (\%) } & \multicolumn{3}{|c|}{ Length of stay (days) } \\
\hline & & & & & & & With AKI & Without AKI & Diff. & With AKI & Without AKI & Diff. \\
\hline [1] & 1,802 & GP & KDIGO & 57.3 & 23.5 & $\begin{array}{l}\text { ICU } \\
\text { Hospital }\end{array}$ & $\begin{array}{l}24 \\
26.9\end{array}$ & $\begin{array}{l}4.7 \\
7.2 \\
\end{array}$ & $\begin{array}{l}+19.3 \\
+19.7\end{array}$ & $\begin{array}{l}\text { ICU: } 6 \\
\text { Hospital: } 15\end{array}$ & $\begin{array}{l}4 \\
12 \\
\end{array}$ & $\begin{array}{l}+2 \\
+3\end{array}$ \\
\hline [2] & 6,647 & GP & AKIN-m & $\begin{array}{l}\text { DC: } 19.1 \\
\text { EC: } 19.9 \\
\text { Both: } 19.2\end{array}$ & $\begin{array}{l}15.5 \\
30.2 \\
23.7\end{array}$ & Hospital & $\begin{array}{l}\text { DC: } 27.6 \\
\text { EC: } 17.6 \\
\text { Both: } 22 \\
\text { RRT: } 32.3\end{array}$ & NS & - & $\begin{array}{l}\text { UTI: DC: } 5 \\
\text { EC: } 6 \\
\text { Hospital: } \\
\text { DC: } 11 \\
\text { EC: } 10\end{array}$ & NS & - \\
\hline$[6]$ & 8,085 & GP & KDIGO & 2.5 & 45 & NS & NS & NS & - & NS & NS & - \\
\hline [7] & 51 & $\begin{array}{l}\text { Post-surgery } \\
\text { cardiac }\end{array}$ & KDIGO & 92.2 & NS & NS & NS & NS & - & NS & NS & - \\
\hline [8] & 1,087 & $\begin{array}{l}\text { Post-surgery } \\
\text { myocardial } \\
\text { injury }\end{array}$ & KDIGO & 5.2 & NS & 30 days & 5.3 & NS & - & NS & NS & - \\
\hline [9] & 7,696 & $\begin{array}{l}\text { Volume } \\
\text { overload }\end{array}$ & $\begin{array}{l}\text { KDIGO } \\
\text { sCr-a }\end{array}$ & $\begin{array}{l}24.2 \\
25.3\end{array}$ & NS & 60 days & 5.4 & NS & - & NS & NS & - \\
\hline [10] & 73 & HIV & RIFLE & All & 23.3 & $\mathrm{ICU}$ & 75.3 & - & - & 1 & - & - \\
\hline [11] & 269 & $\begin{array}{l}\text { GP versus } \\
\text { Sepsis }\end{array}$ & RIFLE & $\begin{array}{l}\text { GP: } 8.9 \\
\text { Sepsis: } 32.3\end{array}$ & $\begin{array}{l}\text { AKI: } 1.9 \\
\text { AKI+Sepsis } \\
15\end{array}$ & $\mathrm{ICU}$ & $\begin{array}{l}\text { AKI: } 66.7 \\
\text { AKI+ Sepsis: } \\
80\end{array}$ & $\begin{array}{l}\text { GP: } 21.2 \\
\text { Sepsis: } 45.2\end{array}$ & $\begin{array}{l}+45.5 \\
+34.8\end{array}$ & $\begin{array}{l}\text { AKI: } 8 \\
\text { AKI+Sepsis } 11\end{array}$ & $\begin{array}{l}\text { GP: } 9 \\
\text { Sepsis: } 13\end{array}$ & $\begin{array}{l}-1 \\
-2\end{array}$ \\
\hline [12] & 152 & GP & RIFLE & 65.8 & 12.4 & $\mathrm{ICU}$ & $\begin{array}{l}\text { AKI: } 52 \\
\text { RRT: } 84.2\end{array}$ & 5.8 & +46.2 & 8.5 & 7 & +1.5 \\
\hline [13] & 476 & GP & AKIN & 52.7 & 0.8 & $\mathrm{ICU}$ & 58 & 27.5 & +30.5 & NS & NS & - \\
\hline$[14]$ & 414 & $\begin{array}{l}\text { Severe acute } \\
\text { pancreatitis }\end{array}$ & AKIN & 69.3 & 59.2 & $\mathrm{ICU}$ & 44.9 & 20.5 & +24.4 & 24 & 22 & +2 \\
\hline [15] & 389 & Cancer & KDIGO & $\begin{array}{l}\text { Cr: } 49.4 \\
\text { UO: } 56.3 \\
\text { Both: } 69.4\end{array}$ & 5.9 & $\begin{array}{l}\text { ICU } \\
180 \text { days }\end{array}$ & $\begin{array}{l}30 \\
51.5\end{array}$ & \begin{tabular}{|l|}
5 \\
15.1
\end{tabular} & $\begin{array}{l}+25 \\
+36.4\end{array}$ & 5 & 2 & +3 \\
\hline [16] & 122 & $\begin{array}{l}V+P \text { versus } \\
V+C\end{array}$ & AKIN & $\begin{array}{l}V+P: 32.7 \\
V+C: 28.8\end{array}$ & $\begin{array}{l}V+P: 18.8 \\
V+C: \\
38.1\end{array}$ & NS & NS & - & - & $\begin{array}{l}V+P: 17.8 \\
V+C: 21.4\end{array}$ & - & - \\
\hline [17] & 74 & RRT & NS & 27 & All & NS & NS & - & - & $\begin{array}{l}\text { ICU: } 18 \\
\text { Hospital: } 36\end{array}$ & - & - \\
\hline [23] & 1,036 & GP & $\begin{array}{l}\text { RIFLE } \\
\text { AKIN } \\
\text { KDIGO } \\
\text { Cys-C } \\
\end{array}$ & $\begin{array}{l}26.4 \\
34.1 \\
37.8 \\
36.1 \\
\end{array}$ & NS & 28 days & $\begin{array}{l}57.9 \\
54.4 \\
51.8 \\
52.1\end{array}$ & NS & - & $\begin{array}{l}13.5 \\
12.9 \\
13.9 \\
13.2 \\
\end{array}$ & $( \pm) 5$ & $\begin{array}{l}+8.5 \\
+7.9 \\
+8.9 \\
+8.2 \\
\end{array}$ \\
\hline [24] & 200 & $\begin{array}{l}\text { Elderly } \\
\text { (>60 years) }\end{array}$ & KDIGO & 27 & NS & $\mathrm{ICU}$ & 48.1 & 15.7 & +32.4 & 11.4 & 5.2 & +6.2 \\
\hline [25] & 137 & Sepsis & AKIN & 77 & 23.4 & $\begin{array}{l}\text { ICU } \\
\text { Hospital } \\
28 \text { days }\end{array}$ & $\begin{array}{l}39 \\
45 \\
38 \\
\end{array}$ & NS & - & NS & NS & - \\
\hline [26] & 573 & $\begin{array}{l}\text { Volume } \\
\text { overload }\end{array}$ & SOFA & 23 & 50.8 & 28 days & 50 & 13.4 & +36.6 & 15.3 & NS & - \\
\hline [27] & 1,234 & RRT & $\begin{array}{l}\text { RIFLE/ } \\
\text { AKIN }\end{array}$ & All & All & $\mathrm{ICU}$ & 69.4 & - & - & 9.8 & - & - \\
\hline [28] & 14,986 & Obesity & KDIGO & 21.1 & NS & $\begin{array}{l}\text { Hospital } \\
1 \text { year }\end{array}$ & $\begin{array}{l}10 \\
12 \\
\end{array}$ & NS & - & NS & NS & - \\
\hline [29] & 832 & GP & $\begin{array}{l}\mathrm{CrCl} / \\
\mathrm{AKIN}\end{array}$ & $\begin{array}{l}\mathrm{CrCl}: 58.3 \\
\text { AKIN: } 27\end{array}$ & $\begin{array}{l}\text { CrCl:9.5 } \\
\text { AKINNS }\end{array}$ & $\mathrm{ICU}$ & $\begin{array}{l}\text { CrCl: } 26.2 \\
\text { AKIN: } \\
\text { NS }\end{array}$ & $\begin{array}{l}\text { CrCl: } 10.7 \\
\text { AKIN: NS }\end{array}$ & $\begin{array}{l}+15.5 \\
-\end{array}$ & $\begin{array}{l}\text { CrCl: } 13.5 \\
\text { AKIN: } \\
\text { NS } \\
\end{array}$ & $\begin{array}{l}\text { CrCl: } 10 \\
\text { AKIN: } \\
\text { NS }\end{array}$ & $\begin{array}{l}+3.5 \\
-\end{array}$ \\
\hline [30] & 190 & GP & $\begin{array}{l}\text { RIFLE } \\
\text { AKIN } \\
\text { KDIGO }\end{array}$ & $\begin{array}{l}62.6 \\
63.2 \\
63.2 \\
\end{array}$ & NS & $\mathrm{ICU}$ & $\begin{array}{l}42.9 \\
42.5 \\
42.5 \\
\end{array}$ & \begin{tabular}{|l|}
17.7 \\
17.7 \\
17.74 \\
\end{tabular} & $\begin{array}{l}+25.2 \\
+24.8 \\
+24.8 \\
\end{array}$ & NS & NS & - \\
\hline$[31]$ & 335 & $\mathrm{CIN}$ & RIFLE & 15.5 & 34.6 & $\begin{array}{l}\text { ICU } \\
\text { Hospital }\end{array}$ & $\begin{array}{l}40.4 \\
53.8 \\
\end{array}$ & \begin{tabular}{|l|}
21.3 \\
35.7 \\
\end{tabular} & $\begin{array}{l}+19.1 \\
+18.1 \\
\end{array}$ & ICU: 14 & ICU: 15 & -1 \\
\hline [32] & 41 & RRT & RIFLE & All & All & $\begin{array}{l}\text { ICU } \\
\text { Hospital }\end{array}$ & $\begin{array}{l}48.8 \\
53.7 \\
\end{array}$ & - & - & 9 & - & - \\
\hline [33] & 548 & GP & RIFLE & 17.2 & 4.3 & 28 days & 49 & NS & & NS & NS & - \\
\hline [34] & 254 & $\begin{array}{l}\text { Infections } \\
\text { diseases }\end{array}$ & RIFLE & All & 27.6 & $\mathrm{ICU}$ & 62.8 & - & - & NS & - & - \\
\hline [35] & 3.107 & GP & $\begin{array}{l}\text { RIFLE/ } \\
\text { AKIN/ } \\
\text { KDIGO }\end{array}$ & \begin{tabular}{|l|}
46.9 \\
38.4 \\
51 \\
\end{tabular} & $( \pm) 20$ & Hospital & $\begin{array}{l}27.8 \\
32.2 \\
27.4 \\
\end{array}$ & \begin{tabular}{|l|}
7 \\
7.1 \\
5.6 \\
\end{tabular} & $\begin{array}{l}+20.8 \\
+25.1 \\
+21.8 \\
\end{array}$ & 5 & 3 & +2 \\
\hline [36] & 2,526 & GP & KDIGO & 46.4 & 18.9 & 28 days & 25.7 & \begin{tabular}{|l|}
10.1 \\
\end{tabular} & +15.1 & 7 & 5 & +2 \\
\hline
\end{tabular}


CONTINUATION

\begin{tabular}{|c|c|c|c|c|c|c|c|c|c|c|c|c|}
\hline \multirow{3}{*}{ Ref } & \multicolumn{2}{|c|}{ Patients } & \multirow{3}{*}{$\begin{array}{l}\text { Criteria } \\
\text { for AKI }\end{array}$} & \multicolumn{9}{|c|}{ Epidemiological data of AKI } \\
\hline & \multirow[t]{2}{*}{$n$} & \multirow[t]{2}{*}{ Setting } & & \multirow{2}{*}{$\begin{array}{l}\text { Incidence } \\
(\%)\end{array}$} & \multirow[t]{2}{*}{ RRT (\%) } & \multirow{2}{*}{$\begin{array}{l}\text { Mortality } \\
\text { endpoint }\end{array}$} & \multicolumn{3}{|c|}{ Mortality (\%) } & \multicolumn{3}{|c|}{ Length of stay (days) } \\
\hline & & & & & & & With AKI & Without AKI & Diff. & With AKI & Without AKI & Diff. \\
\hline$[37]$ & 65 & GP & $\begin{array}{l}\text { RIFLE/ } \\
\text { AKIN }\end{array}$ & All & 48 & ICU & 69 & NS & - & NS & NS & - \\
\hline$[38]$ & 901 & Trauma & AKIN & 6 & 19 & 30 days & $\begin{array}{l}29.6 \\
\text { RRT: } 50\end{array}$ & 7.9 & +21.7 & NS & NS & - \\
\hline [39] & 114 & $\mathrm{ClAl}$ & AKIN & 58.8 & 28.9 & $\begin{array}{l}\text { ICU } \\
28 \text { days }\end{array}$ & $\begin{array}{l}17.9 \\
23.9\end{array}$ & NS & - & NS & NS & - \\
\hline$[40]$ & 360 & GP & AKIN & 59.7 & $( \pm) 2.3$ & ICU & $( \pm) 60.2$ & 18.6 & +41.6 & $\begin{array}{l}\text { ICU ( } \pm): \\
11.9 \\
\text { Hospital: }( \pm) \\
22.7\end{array}$ & $\begin{array}{l}\text { ICU: } 7.2 \\
\text { Hospital: } 27.2\end{array}$ & $\begin{array}{l}+4.7 \\
-4.5\end{array}$ \\
\hline [41] & 715 & GP & RIFLE & 16.1 & 39.1 & $\begin{array}{l}\text { ICU } \\
28 \text { days }\end{array}$ & $\begin{array}{l}7.8 \\
49.5\end{array}$ & NS & - & ICU: 11 & NS & - \\
\hline$[42]$ & 40 & RRT & NS & All & All & 30 days & 52.5 & - & - & NS & - & - \\
\hline$[43]$ & 44 & GP & AKIN & All & 43.2 & $\mathrm{ICU}$ & 43.2 & NS & - & NS & NS & - \\
\hline$[44]$ & 627 & GP & $\begin{array}{l}\text { RILE/ } \\
\text { AKIN }\end{array}$ & $\begin{array}{l}\text { RIFLE: } 69.4 \\
\text { AKIN: } \\
51.8 \\
\text { Both: } 74.4\end{array}$ & 5.4 & 90 days & $\begin{array}{l}40.9 \\
44.6\end{array}$ & $\begin{array}{l}19.8 \\
23.5\end{array}$ & +21.1 & 14 & 14 & - \\
\hline [45] & 149 & CIN & RIFLE & 15.4 & 13 & $\mathrm{ICU}$ & 52 & 19 & +33 & 13 & 12 & +1 \\
\hline$[46]$ & 2,901 & GP & $\begin{array}{l}\text { AKIN/ } \\
\text { KDIGO }\end{array}$ & 39.3 & 10.2 & $\begin{array}{l}\text { Hospital } \\
90 \text { days }\end{array}$ & $\begin{array}{l}25.6 \\
33.7 \\
\end{array}$ & NS & - & 3.7 & NS & - \\
\hline$[47]$ & 624 & Surgical & RIFLE & 58 & 8 & $\begin{array}{l}\text { Hospital } \\
1 \text { year }\end{array}$ & $\begin{array}{l}19 \\
35\end{array}$ & \begin{tabular}{|l|}
4 \\
14 \\
\end{tabular} & $\begin{array}{r}+15 \\
+21 \\
\end{array}$ & $\begin{array}{l}\text { ICU: } 6 \\
\text { Hospital: } 19\end{array}$ & $\begin{array}{l}\text { ICU: } 3 \\
\text { Hospital: } 9\end{array}$ & $\begin{array}{l}+3 \\
+10 \\
\end{array}$ \\
\hline$[48]$ & 274 & RRT & RIFLE & All & All & $\begin{array}{l}\text { ICU } \\
\text { Hospital }\end{array}$ & $\begin{array}{l}58.4 \\
62 \\
\end{array}$ & - & - & $\begin{array}{l}\text { ICU: } 14 \\
\text { Hospital: } 22\end{array}$ & - & - \\
\hline [49] & 182 & Post-partum & $\begin{array}{l}\mathrm{Cr} \geq \\
89 \mu \mathrm{mol} / \\
\text { RIFLE }\end{array}$ & 37.3 & 28 & NS & NS & NS & - & 4 & 2 & +2 \\
\hline$[50]$ & 1,769 & GP & AKIN & 28.9 & NS & $\begin{array}{l}30 \text { days } \\
1 \text { year }\end{array}$ & $\begin{array}{l}13.3 \\
28.8 \\
\end{array}$ & \begin{tabular}{|l|}
6.0 \\
16.5 \\
\end{tabular} & $\begin{array}{l}+7.3 \\
+12.3\end{array}$ & NS & NS & - \\
\hline [51] & 40 & GP & RIFLE & 75 & NS & $\mathrm{ICU}$ & 30 & 10 & +20 & NS & NS & - \\
\hline [52] & 1,070 & GP & RIFLE & $\begin{array}{l}\text { Men: } 35.8 \\
\text { Women: } 38.7 \\
\text { Both: } 37.3\end{array}$ & NS & NS & NS & NS & - & NS & NS & - \\
\hline [53] & 445 & GP & KDIGO & 48.8 & 33.2 & 90 days & 15.3 & NS & - & $( \pm) 4.3$ & 2.1 & 2.2 \\
\hline [54] & 27 & MV & RIFLE & All & NS & $\mathrm{ICU}$ & 44.4 & NS & - & NS & NS & - \\
\hline$[55]$ & 3,350 & GP & $\begin{array}{l}\text { RIFLE/ } \\
\text { AKIN }\end{array}$ & $\begin{array}{ll}21 \\
21.1\end{array}$ & NS & ICU & $\begin{array}{l}46.5 \\
47 \\
\end{array}$ & NS & - & NS & NS & - \\
\hline
\end{tabular}

"Note: Only articles published between January 2013 and February 2017. Abbreviations: AKIN - Acute Kidney Injury Network; AKIN-m - AKIN modified; CIAI - complicated intra-abdominal infection; $\mathrm{CIN}$ - Contrast-induced nephropathy; $\mathrm{ClCr}$ - Clearence of creatinine; $\mathrm{Cr}$ - Creatinine; Cys-C - Cystatin C; DC - Developed countries; Diff. - Simple difference between patients with and without AKl; EC - Emerging countries; GP - General population; HIV - Human Immunodeficiency Virus; KDIGO - Kidney Disease Improving: Global Outcomes; MV - Mechanical ventilation; NS - Not specified; Ref - Reference; RIFLE - Risk, Injury, Failure, Loss, End-stage kidney disease; RRT - Renal replacement therapy; sCr-a - Serum creatinine adjusted to the water balance; SOFA - Sequential Organ Failure Assessment; $\cup O$ - Urine Output; $V+P$ - Vancomycin with piperacillin-tazobactam; $V+C$ - Vancomycin with cefepime.

increases linearly with age, as well as the chance of needing RRT, which further increases the mortality rate of patients. ${ }^{1,2,14,17,24}$

Almost all studies listed in Table 1 present diabetes mellitus and systemic arterial hypertension as the chronic diseases that are the most prevalent risk factors in critically ill adults with AKI. Moreover, these are also the chronic conditions that frequently increase morbidity and mortality for AKI in critically ill patients who are septic, ${ }^{11,16,25}$ with fluid overload, ${ }^{2,9,26}$ making use of nephrotoxic drugs ${ }^{16}$ or who have undergone major surgeries., ${ }^{7,8}$ Other chronic pathological conditions that are also noted as risk factors for AKI incidence and mortality in critically ill patients include cardiovascular, $, 17,27-30$ respiratory ${ }^{10,31}$ cerebrovascular, ${ }^{16}$ cirrhosis, ${ }^{32,33}$ can$\operatorname{cer}^{15,25}$, and human immunodeficiency virus infection. $^{10,34}$

Several studies have shown baseline renal function as one of the most important risk factors for AKI. Luo et al. ${ }^{35}$ performed prospective analysis of a database from Beijing (China), with more than three 
thousand adult patients, and observed that AKI patients identified by KDIGO criteria already had worse baseline renal function in comparison with those without AKI. In this same sense, Yokota et al. ${ }^{24}$ in a prospective study with critically ill elderly patients verified that AKI patients presented worse baseline serum creatinine. Worse baseline renal function also was an AKI risk factor in the study performed by Wang et al. ${ }^{36}$

In others studies, ${ }^{12,37-39}$ patients with AKI during ICU stay are the ones with higher serum creatinine at ICU admission, and in the studies performed by Podoll et al. ${ }^{38}$ and Peres et al. ${ }^{12}$ it was also associated with a higher risk for mortality.

In the presence of sepsis, the reported incidence of AKI was greater than $70 \%$, and mortality rate reached $80 \%$, higher in patients undergoing RRT, 1,10,11,14,17,24,34,36,37,39-43 Sepsis was also an independent factor that increased the length of stay of individuals in ICUs. ${ }^{11}$ The pathophysiological dynamics of the interaction between sepsis and AKI are not fully understood, and the association between sepsis and AKI in ICU patients can cause vascular, glomerular, tubular, and interstitial damage in the kidneys. Nevertheless, it is believed that the inflammatory process, oxidative stress, and apoptosis act as the link of the interaction between the events (see Figure 1). Vasodilation, hypoperfusion, and ischemic injury are probably the primary deleterious effects of this interaction. ${ }^{3,5,11,20}$

Nephrotoxic agents were an important factor contributing to AKI among critically ill patients ${ }^{44}$. Two recent studies have shown distinct results on the effect of contrast-induced nephropathy (CIN) ${ }^{31,45}$ Hocine et al. ${ }^{45}$ assessed 149 patients in a single-center study in
Belgium and Kim et al..$^{31} 335$ patients in the Republic of Korea. Although these studies showed a similar incidence of CIN, approximately $15 \%$, CIN patients had a mortality rate $11 \%$ higher than those without CIN. ${ }^{45}$ In another study, the ICU length of stay of patients with and without CIN was similar, nearly 15 days. ${ }^{31}$ It should be noted that the pathophysiological genesis of CIN is not yet fully determined; however, the mechanisms may involve renal medullary ischemia and renal tubular damage by toxicity. ${ }^{31,45}$

Additionally, we verified that fluid overload might represent an independent risk factor for AKI development, need for RRT, and mortality. ${ }^{9,26,32,36,44}$ Fluid overload can promote renal interstitial edema and consequent water and saline retention, increased interstitial pressure, reduction of renal blood flow and glomerular filtration rate. ${ }^{26,32}$ Moreover, fluid overload is also a risk factor for increased intra-abdominal pressure, central venous pressure, and renal venous pressure, which contribute to worsening renal function. . $6,32,36$

The use of diuretics in critically ill patients is frequent and one of the first strategies to minimize the consequences of fluid overload, but the administration may increase the risk of death in AKI patients. ${ }^{37,46}$ In South America, the administration of diuretics was associated with higher mortality of critically ill AKI patients. ${ }^{37}$ A multicenter Finnish study was identified in which $78.1 \%$ of patients who acquired AKI in the ICU were treated with vasoactive drugs. ${ }^{46}$ In addition, the authors reported that over one-third of the AKI patients that used diuretics had hemodynamic stability or severe sepsis, and the use of diuretics was identified as a risk factor for the increase of AKI incidence.

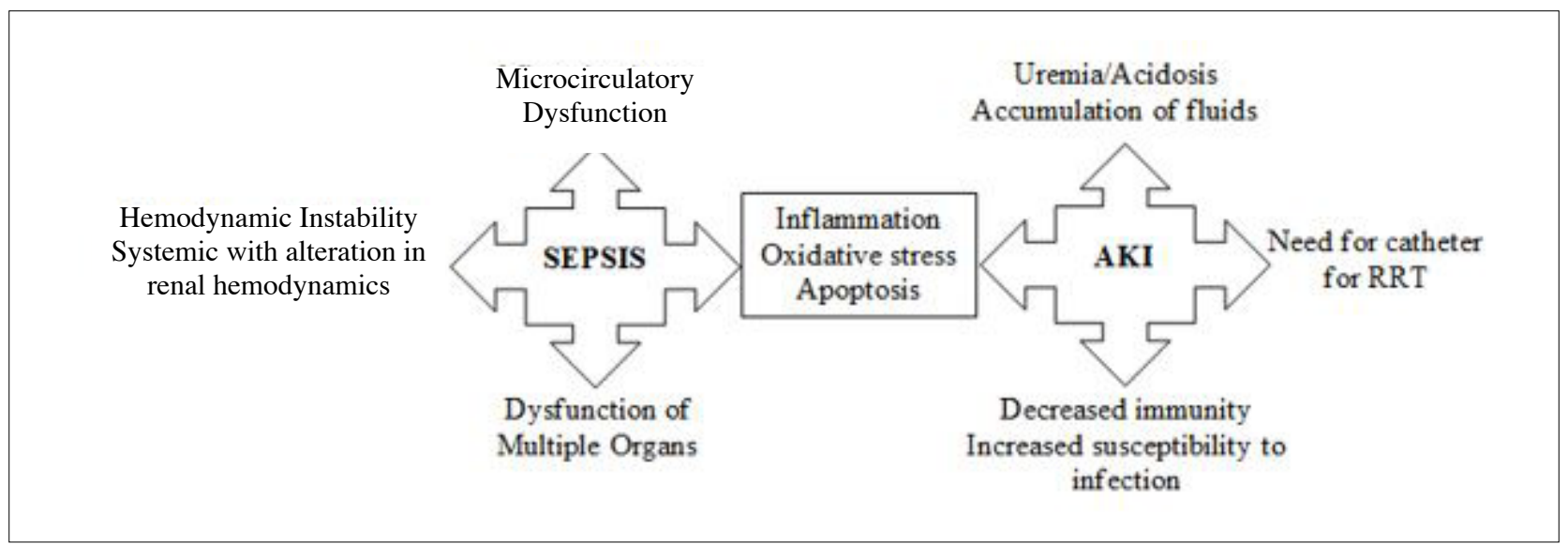

Note: AKI - Acute kidney injury; RRT - Renal replacement therapy 
In the United States, the combined therapy of vancomycin with piperacillin-tazobactam resulted in a higher AKI rate in ICU patients. However, no statistically significant differences were found regarding the need for RRT among patients taking vancomycin combined with cefepime. ${ }^{16}$

In a small prospective cohort, Nascimento et al. ${ }^{7}$ evaluated 51 patients after bypass surgery and reported AKI incidence of $92.2 \%$. In another study, the AKI occurrence was $5.2 \%$, and the syndrome was an independent risk factor for myocardial injury. ${ }^{8}$

In addition to cardiac procedures, neurosurgeries, and transplants, ${ }^{1}$ gastrointestinal, orthopedics, gynecological and urological surgeries ${ }^{47}$ have also been associated with the occurrence of AKI in critically ill patients and are responsible for increasing the risk of death.

The RRT need can significantly increase both the length of hospital stay and patient mortality. In studies performed in Brasil, the mortality in patients undergoing RRT reached $58.4 \%{ }^{48}$ in the Southeast region and $84.2 \%{ }^{12}$ in the South region, and the mean length of hospital stay reached 36 days. ${ }^{17}$ In two studies, the patients' mortality on continuous RRT modality was around $50 \%,{ }^{43,32}$ and in one study, the mortality in RRT by continuous and intermittent modalities reached $74.4 \%{ }^{27}$

There are studies in which the need for mechanical ventilation,,$^{2,28,33}$ as well as elevated central venous pressure ${ }^{30}$ and metabolic acidosis ${ }^{28,42,45}$ have proved to be risk factors for AKI and death of patients who already presented the injury. Other risk factors are present in special populations such as patients with infectious diseases, ${ }^{28}$ severe acute pancreatitis,${ }^{15}$ overweight/obesity ${ }^{32}$ obstetric complications, ${ }^{49}$ malaria $^{42}$, and trauma victims. ${ }^{38}$

\section{CONCLUSION}

AKI incidence presented high variability among the studies, and the different criteria to define the cases is among the reasons. Availability of local resources, renal replacement therapy needs, serum creatinine at ICU admission, volume overload, and sepsis, among others, influence the mortality rates in AKI patients. This literature review demonstrated that a varied combination of risk factors are linked to the increasing incidence and persistence of high mortality rates in the ICU. We believe that knowing the epidemiological aspects of AKI and identifying its main risk factors to achieve early diagnosis are the first steps toward enhancing patient outcomes.

\section{Declaration of Conflicting Interests}

The author(s) declared no potential conflicts of interest concerning the research, authorship, or publication of this article.

Funding: There was no funding for this article.

\section{Highlights}

The incidence of AKI in critically ill patients is worrisome, regardless of geographical location;

The value of serum creatinine when the patient is admitted to the ICU can help the early diagnosis of AKI;

Sepsis persists with the cause-effect role of AKI, showing a strong association both to the incidence and to the increased mortality of critically ill patients;

Requiring RRT continues to have a relationship with worse outcomes;

Reducing preventable cases and deaths is a challenge to be faced by all health staffs.

\section{Author Contributions}

Passoni dos Santos R contributed with (1) the conception and design of the work, the acquisition, analysis, and interpretation of the data, (2) drafting the article or revising it critically for important intellectual content; (3) final approval of the version to be submitted; (4) agreement to be accountable for all aspects of the work in ensuring that questions related to the accuracy or integrity of any part of the work are appropriately investigated and resolved.

Carvalho ARS contributed with (1) drafting the article and revising it critically for important intellectual content; (2) final approval of the version to be submitted.

Peres LAB contributed with (1) the conception and design of the work, the acquisition, analysis, and interpretation of the data, (2) drafting the article or revising it critically for important intellectual content; (3) final approval of the version to be submitted.

Ronco C and Macedo E contributed with (1) drafting the article and revising it critically for important intellectual content; (2) final approval of the version to be submitted. 


\section{RESUMO}

INTRODUÇÃO: Injúria renal aguda (IRA) é um evento frequente entre pacientes criticamente enfermos internados em unidade de terapia intensiva (UTI) e representa um problema de saúde pública global, sendo imperativa uma abordagem interdisciplinar.

OBJETIVO: Investigar, por meio de revisão de literatura, a epidemiologia da IRA em UTIs.

MÉTOdos: Pesquisa on-line nas bases de dados Medline, Scientific Electronic Library Online e Literatura Latino-americana e do Caribe em Ciências da Saúde, com análise dos 47 estudos de maior relevância publicados entre 2010 e 2017.

RESULTADOS: Foram analisados dados de 67.033 pacientes, internados em mais de 300 UTIs de diferentes regiões do mundo. A incidência global de IRA variou de 2,5\% a 92,2\% e a mortalidade, entre 5\% e 80\%. O tempo de internação em UTI variou de cinco a 21 dias, enquanto que a necessidade de terapia renal substitutiva, de 0,8\% a 59,2\%. Pacientes com IRA apresentam índice de mortalidade substancialmente maior e tempo de internação mais elevado, em comparação com pacientes sem IRA.

CONCLUSÃO: A incidência de IRA apresentou alta variabilidade entre os estudos e, dentre os motivos, estão os diferentes critérios utilizados para definição dos casos. Disponibilidade de recursos locais, necessidade de terapia renal substitutiva, creatinina na admissão na UTI, sobrecarga volêmica e sepse, dentre outros, influenciam as taxas de mortalidade entre os pacientes com IRA.

PALAVRAS-CHAVE: Lesão renal aguda. Unidades de terapia intensiva. Epidemiologia. Fatores de risco.

\section{REFERENCES}

1. Hoste EA, Bagshaw SM, Bellomo R, Cely CM, Colman R, Cruz DN, et al. Epidemiology of acute kidney injury in critically ill patients: the multinational AKI-EPI study. Intensive Care Med. 2015;41(8):1411-23.

2. Bouchard J, Acharya A, Cerda J, Maccariello ER, Madarasu RC, Tolwani AJ, et al. A prospective international multicenter study of $A K I$ in the intensive care unit. Clin | Am Soc Nephrol. 2015;10(8):1324-31.

3. Lameire NH, Bagga A, Cruz D, De Maeseneer J, Endre Z, Kellum A, et al. Acute kidney injury: an increasing global concern. Lancet. 2013;382(9887):170-9.

4. James MT, Tonelli M; Alberta Kidney Disease Network. Financial aspects of renal replacement therapy in acute kidney injury. Semin Dial. 2011;24(2):215-9.

5. Mehta RL, Burdmann EA, Cerdá J, Feehally J, Finkelstein F, García-García $G$, et al. Recognition and management of acute kidney injury in the International Society of Nephrology Oby25 Global Snapshot: a multinational cross-sectional study. Lancet. 2016;387(10032):2017-25.

6. Zampieri FG, Ranzani OT, Azevedo LC, Martins ID, Kellum ID, Libório AB Lactated ringer is associated with reduced mortality and less acute kidney injury in critically ill patients: a retrospective cohort analysis. Crit Care Med. 2016;44(12):2163-70.

7. Nascimento MS, Aguiar TC, Silva AVE, Duarte TTP, Magro MCS. Acute kidney injury in the postoperative period of cardiac surgery. Acta Paul Enferm. 2015;28(4):367-73.

8. Zhao XI, Zhu FX, Li S, Zhang HB, An YZ. Acute kidney injury is an independent risk factor for myocardial injury after noncardiac surgery in critical patients. J Crit Care. 2017;39:225-31.

9. Thongprayoon C, Cheungpasitporn W, Srivali N, Ungprasert P, Kittanamongkolchai W, Kashani K. The impact of fluid balance on diagnosis, staging, and prediction of mortality in critically ill patients with acute kidney injury. | Nephrol. 2016;29(2):221-7.

10. Luna LDS, Soares DS, Silva Junior GB, Cavalcante MG, Malveira LRC, Meneses GC, et al. Clinical characteristics, outcomes and risk factors for death among critically ill patients with HIV-related acute kidney injury. Rev Inst Med Trop Sao Paulo. 2016:58:52.

11. Martinuzzi A, Ferraresi E, Orsatti M, Palaoro A, Alcántara S, Corball A, et al. Sepsis e injuria renal aguda en una unidad de cuidados intensivos. Revista Cubana de Alimentación y Nutrición. 2014;24(2 suppl.1):S53-S61.

12. Peres $L A$, Wandeur $V$, Matsuo T. Predictors of acute kidney injury and mortality in an intensive care unit. J Bras Nefrol. 2015;37(1):38-46.

13. Masewu A, Makulo |R, Lepira F, Amisi EB, Sumaili EK, Bukabau |, et al. Acute kidney injury is a powerful independent predictor of mortality in critically ill patients: a multicenter prospective cohort study from Kinshasa, the Democratic Republic of Congo. BMC Nephrol. 2016;17(1):118.

14. Zhou J, Li Y, Tang Y, Liu F, Yu S, Zhang L, et al. Effect of acute kidney injury on mortality and hospital stay in patient with severe acute pancreatitis. Nephrology (Carlton). 2015;20(7):485-91.
15. Córdoba-Sánchez BM, Herrera-Gómez A, Ñamendys-Silva SA. Acute kidney injury classified by serum creatinine and urine output in critically ill cancer patients. Biomed Res Int. 2016;2016:6805169.

16. Hammond DA, Smith MN, Painter JT, Meena NK, Lusardi K. Comparative incidence of acute kidney injury in critically ill patients receiving vancomycin with concomitant piperacillin-tazobactam or cefepime: a retrospective cohort study. Pharmacotherapy. 2016;36(5):463-71.

17. Luft |, Boes AA, Lazzari DD, Nascimento ERP, Busana IA, Canever BP. Chronic kidney injury at an intensive care service: clinical characteristics and outcomes. Cogitare Enferm. 2016;21(2):1-9.

18. Ricci Z, Ronco C, D'Amico G, De Felice R, Rossi S, Bolgan I, et al. Practice patterns in the management of acute renal failure in the critically ill patient: an international survey. Nephrol Dial Transplant. 2006;21(3):690-6.

19. Selby NM, Fluck RJ, Kolhe NV, Taal MW. International criteria for acute kidney injury: advantages and remaining challenges. Plos Med. 2016;13(9):e1002122.

20. Uchino S, Kellum JA, Bellomo R, Doig GS, Morimatsu H, Morgera S, et al; Beginning and Ending Supportive Therapy for the Kidney (BEST Kidney) Investigators. Acute renal failure in critically ill patients: a multinational, multicenter study. JAMA. 2005;294(7):813-8.

21. Anderson S, Eldadah B, Halter JB, Hazzard WR, Himmelfarb J, Horne FM, et al. Acute kidney injury in older adults. J Am Soc Nephrol. 2011;22(1):28-38.

22. Correa-Rotter R, Naicker $S$, Katz II, Agarwal SK, Herrera Valdes R, Kaseje D, et al; ISN-COMGAN Bellagio Study Group 2004. Demographic and epidemiologic transition in the developing world: role of albuminuria in the early diagnosis and prevention of renal and cardiovascular disease. Kidney Int Suppl. 2004(92):S32-7.

23. Zhou |, Liu Y, Tang Y, Liu F, Zhang L, Zeng X, et al. A comparison of RIFLE, $A K I N, K D I G O$, and Cys-C criteria for the definition of acute kidney injury in critically ill patients. Int Urol Nephrol. 2016;48(1):125-32.

24. Yokota LG, Sampaio BM, Rocha E, Balbi AL, Ponce D. Acute kidney injury in elderly intensive care patients from a developing country: clinical features and outcome. Int Nephrol Renovasc Dis. 2017;10:27-33.

25. Legrand M, Dupuis C, Simon C, Gayat E, Mateo J, Lukaszewicz AC, et al. Association between systemic hemodynamics and septic acute kidney injury in critically ill patients: a retrospective observational study. Crit Care. 2013;17(6):R278.

26. Teixeira C, Garzotto F, Piccini P, Brienza N, Lannuzzi M, Gramaticopolo S, et al; NEFROlogia e Cura INTensiva (NEFROINT) investigators. Fluid balance and urine volume are independent predictors of mortality in acute kidney injury. Crit Care. 2013;17(1):R14

27. Czempik P, Ciesla D, Knapik P, Krzych L. Outcomes of patients with acute kidney injury with regard to time of initiation and modality of renal replacement therapy: first data from the Silesian Registry of Intensive Care Units. Kardiochir Torakochirurgia Pol. 2016;13(2):122-9. 
28. Danziger J, Chen K, Lee J, Feng M, Mark RG, Celi LA, et al. Obesity, acute kidney injury, and mortality in critical illness. Crit Care Med. 2016;44(2):328-34.

29. Herrera-Gutiérrez ME, Seller-Pérez G, Sánchez-Izquierdo-Riera JA, Maynar-Moliner J; COFRADE investigators group. Prevalence of acute kidney injury in intensive care units: the "COrte de prevalencia de disFunción RenAl y DEpuración en críticos" point-prevalence multicenter study. J Crit Care. 2013;28(5):687-94

30. Levi TM, Souza SP, Magalhaes JG, Carvalho MS, Cunha AL, Dantas JG, et al. Comparison of the RIFLE, AKIN and KDIGO criteria to predict mortality in critically ill patients. Rev Bras Ter Intensiva. 2013;25(4):290-6.

31. Kim MH, Koh SO, Kim EJ, Cho JS, Na SW. Incidence and outcome of contrast-associated acute kidney injury assessed with Risk, Injury, Failure, Loss, and End-stage kidney disease (RIFLE) criteria in critically ill patients of medical and surgical intensive care units: a retrospective study. BMC Anesthesiol. 2015;15:23.

32. Gaião SM, Gomes AA, Paiva JA. Prognostics factors for mortality and renal recovery in critically ill patients with acute kidney injury and renal replacement therapy. Rev Bras Ter Intensiva. 2016;28(1):70-7.

33. Singh S, Patra AK, Patel B, Ramesh GS, Sharma VK, Ravishankar V, et al. Acute renal failure in the ICU setting: a prospective observational study. Med | Armed Forces India. 2016;72(3):236-41.

34. Daher EF, Junior Silva GB, Vieira AP, Souza JB, Falcão FS, Costa CR, et al. Acute kidney injury in a tropical country: a cohort study of 253 patients in an infectious diseases intensive care unit. Rev Soc Bras Med Trop. 2014;47(1):86-9.

35. Luo X, Jiang L, Du B, Wen Y, Wang M, Xi X, Beijing Acute Kidney Injury Trial (BAKIT) workgroup. A comparison of different diagnostic criteria of acute kidney injury in critically ill patients. Crit Care. 2014;18(4):R144.

36. Wang N, Jiang L, Zhu B, Wen Y, Xi XM; Beijing Acute Kidney Injury Trial (BAKIT) Workgroup. Fluid balance and mortality in critically ill patients with acute kidney injury: a multicenter prospective epidemiological study. Crit Care. 2015;19:371.

37. Miralles FM, Ayala RA, Giménez E, Okinaka S. Terapia de reemplazo renal en pacientes de terapia intensiva en el Hospital Central del Instituto de Previsión Social. Nefrología Argentina. 2015;13(2):51-9.

38. Podoll AS, Kozar R, Holcomb JB, Finkel KW. Incidence and outcome of early acute kidney injury in critically-ill trauma patients. PLoS One. 2013;8(10):e77376.

39. Suarez-de-la-Rica A, Anillo V, Montero A, Hernandez-Gancedo C, Lopez-Tofiño A, Gilsanz F, et al. Risk factors for acute kidney injury in critically ill patients with complicated intra-abdominal infection. J Crit Care. 2017;38:104-8

40. Herrera-Méndez |, Sánchez-Velázquez LD, González-Chávez A, Rodríguez-Terán $\mathrm{G}$. Incidence of acute renal failure in the intensive care unit at the General Hospital of Mexico: risk factors and associated morbidity and mortality. Rev Med Hosp Gen Méx. 2015;78(2):62-6.

41. Korula S, Balakrishnan S, Sundar S, Paul V, Balagopal A. Acute kidney injury-incidence, prognostic factors, and outcome of patients in an intensive care unit in a tertiary center: a prospective observational study. Indian J Crit Care Med. 2016;20(6):332-6.

42. Kwizera A, Tumukunde J, Ssemogerere L, Ayebale E, Agaba P, Yakubu J, et al. Clinical characteristics and 30-day outcomes of intermittent hemodialysis for acute kidney injury in an african intensive care unit. Biomed Res Int. 2016;2016:2015251.

43. Rodríguez MM, Machado VRN, Cedeño JLV. Caracterización clínico-analítica de pacientes con lesión renal aguda en una unidad de cuidados intensivos de adulto, Cienfuegos, 2014. Rev Cub Int Emerg. 2016;15(3):55-69.

44. Salgado G, Landa M, Masevicius D, Gianassi S, San-Román JE, Silva L, et al. Acute renal failure according to the RIFLE and AKIN criteria: a multicenter study. Med Intensiva. 2014;38(5):271-7.

45. Hocine A, Defrance P, Lalmand J, Delcour C, Biston P, Piagnerelli M. Predictive value of the RIFLE urine output criteria on contrast-induced nephropathy in critically ill patients. BMC Nephrol. 2016;17:36.

46. Nisula S, Kaukonen K-M, Vaara ST, Korhonen AM, Poukkanen M, Karlsson S, et al; FINNAKI Study Group. Incidence, risk factors and 90-day mortality of patients with acute kidney injury in Finnish intensive care units: the FINNAKI study. Intensive Care Med. 2013;39(3):420-8.

47. Harris DG, McCrone MP, Koo G, Weltz AS, Chiu WC, Scalea TM, et al. Epidemiology and outcomes of acute kidney injury in critically ill surgical patients. J Crit Care. 2015;30(1):102-6.

48. Valente C, Soares M, Rocha E, Cardoso L, Maccariello E. The evaluation of sequential platelet counts has prognostic value for acute kidney injury patients requiring dialysis in the intensive care setting. Clinics (Sao Paulo). 2013;68(6):803-8

49. Jonard M, Ducloy-Bouthors AS, Boyle E, Aucourt M, Gasan G, Jourdain M, et al. Postpartum acute renal failure: a multicenter study of risk factors in patients admitted to ICU. Ann Intensive Care. 2014;4:36.

50. Boltansky A, Bassa C, Melani S, Sepúlveda A, Maldonado I, Postigo J, et al. Incidence and consequences of acute kidney injury among patients admitted to critical care units. Rev Med Chil. 2015;143(9):1114-20.

51. Cerqueira DP, Tavares JR, Machado RC. Predictive factors for renal failure and a control and treatment algorithm. Rev Lat Am Enfermagem. 2014;22(2):211-7.

52. Ephraim RKD, Darkwah KO, Sakyi SA, Ephraim M, Antoh EO, Adoba P. Assessment of the RIFLE criteria for the diagnosis of Acute Kidney Injury; a retrospective study in South-Western Ghana. BMC Nephrol. 2016;17(1):99.

53. Marttinen M, Wilkman E, Petäjä L, Suojaranta-Ylinen R, Pettilä V, Vaara ST. Association of plasma chloride values with acute kidney injury in the critically ill: a prospective observational study. Acta Anaesthesiol Scand. 2016;60(6):790-9.

54. Santos LL, Magro MCS. Mechanical ventilation and acute kidney injury in patients in the intensive care unit. Acta Paul Enferm. 2015;28(2):146-51.

55. Talaat A, Elshahawy E, El Hammady AM, El-Assal M, Abdulhah S. Epidemiology, clinical characteristics and outcome of acute kidney injury in intensive care units in Egyptian patients. Life Science J. 2014;11(7):220-4 